\title{
Governmental Domination in Toll Road Development (A Study on Social Effect of Toll Road Development in Boyolali Regency)
}

\author{
Budiman Widodo ${ }^{1}$, Winarti ${ }^{2}$ \\ \{ budimanwidodo5@gmail.com $^{1}$,Winartititik@yahoo.co.id $\left.{ }^{2}\right\}$ \\ Surakarta University ${ }^{1}$, Slamet Riyadi University ${ }^{2}$
}

\begin{abstract}
Indonesian population number increases over times, reaching \pm 268.9 millions people in 2018. To compensate the population growth rate, road infrastructure is required; the choice of infrastructure development as the strategy to improve economic growth makes the toll road development increases very rapidly. This research was intended to analyze, firstly, the improved welfare of the communities around the toll road; secondly, to analyze the top-down toll road development model resulting in the low public participation; and thirdly to find the road toll development model with surrounding community partnership by giving them business access. The analysis method employed was interactive analysis. The result of study showed unimproved welfare of society surrounding Toll Road, Toll Road development as government domain in which no social participation within it, and the community's very poor access to business. The author recommends the policy maker to involve people surrounding the toll road in working on the farmland along the toll road edge, to give them access to establish business in rest area, and to enable them to have share as the compensation for the land.
\end{abstract}

Keywords: Domination, infrastructure, public participation

\section{Introduction}

As the state with the $4^{\text {th }}$ largest population number in the world, about 268.9 millions populations [12], Indonesia has big potency and challenge all at once.

The density of Indonesian cities is characterized with traffic jam occurring in nearly all Indonesian cities, generating some problem to solve. The policy of spurring the growth of particularly automobile industrial sector, as indicated with \pm 1.1 millions four-wheel vehicles in 2018 [12], results in traffic jam problem on the streets in Indonesian city, on the other hand, the existence of vehicle contributes considerably to tax. The choice of policy taken by the government is to increase the volume of highway through toll-road construction.

The construction of toll road infrastructure is projected to construct $1850 \mathrm{~km}$ up to 2019 ; this figure increases dramatically compared with that in 1975, when only $750 \mathrm{~km}$-toll road was constructed, with the financing scheme of Cooperation between Government and Enterprises (KPBU) with fund composition of 1,482 trillions (41.3\%) from central and regional 
governments, 799 trillions (22.2\%) from State-Owned Enterprise and the rest $(36.5 \%)$ from private (Kompas: December 29, 2017: p. 18). In addition to toll-road, government also constructed (regular) national road as long as the planned, 1,602.99 km in south-south track with the financing scheme of Islam Development Bank (IDB)'s loan of IDR 5.358 trillions.

The development of many infrastructures is expected to improve regional economic growth, rather than to widen the regional economic gap, because infrastructure can drag those in the bottom to deal with their disadvantage. Indonesia's global competitiveness index increases in 2017-2018, on the 36th rank, compared with the 41st rank in 2016-2017. The more significant increase occurs in the index, on 52nd rank, compared with 60th rank in 2016-2017. The improvement of infrastructure's competitiveness was contributed by toll road construction. Nevertheless, the increase of competitiveness index is characterized with Indonesian low infrastructure availability; the ratio of infrastructure availability to gross domestic product is about 38 percents, compared with 76 percents in China and 58 percents in India.

In addition to the two actors, government and private, contributing considerably to the finance, the role of society has not gotten adequate portion. It is logical recalling that viewed from financial aspect the society does not have power to participate in finance. However, it is noteworthy that the development is conducted for people, so it is the people who should enjoy the product of development rather than become spectators only or even are condemned due to the development conducted. Development is expected to impact on their life welfare; for that reason the thinking of social effect on the society should be included into infrastructure development.

The development of toll-road infrastructure, starting with planning and operation, involves the people very minimally so far, particularly the region affected with the project. The level of infrastructure development planning is under central government's authority, either financing or location aspect, toll-road development is the priority of national strategic project. At implementation level, provincial or regency/municipal government begins to be involved in socialization and land acquisition stages. At these two stages, people are limited to receiving information about development plan and possible compensation for the land affected with the project. At this stage, it can be seen clearly that people have weak bargaining power. It can be understood because the development conducted by state is intended to broader purpose; it is legitimate for the state to conduct legal and formal approach by means of top down model through its bureaucracy because the state should win.

The state's domination in the development will not be a matter as long as it is intended to the nation's justice and prosperity. The state is authorized to design "agenda setting" [4]. Wherever the state will go, the important point is that the agenda must not sacrifice the people's interest. It has been realized that it will be difficult to avoid some parties from being sacrificed, because conflict of interest will face a policy with a question of agree or disagree. This research is intended to find out the conflict of interest by minimizing the loss generated and the effect on society, with "PARCIPATORY CENTER POWER" development model being an alternative development model, particularly for toll-road infrastructure.

\subsection{Problem Identification}

1. The development of toll-road infrastructure particularly becomes Indonesian government's policy option, as it is intended to accelerate the distribution of product (commodity) and to compensate the automobile industrial growth; on the other hand, the construction of toll road uses productive farmland and condemns or expels the farmers.

2. The construction of toll road is designed by central government (state's domination), with very low participation of people (public) and local government. 
3. The people surrounding toll road has no economic access directly to the presence of toll road

\subsection{Problem Statement}

Why do farmers and local people affected by toll road construction not have access to the road project so that they cannot enjoy the product of development conducted by the government?

\subsection{Objectives}

1. To analyze whether or not there is an improvement of welfare among the people surrounding toll road or instead they are deprived from their occupation as farmer

2. To analyze the "top down" toll-road development model and to find out whether or not it is leads to low public participation

3. To look for partnership model for business access

\subsection{Benefit}

1. Contributing to the formulation of governmental policy related to social problem.

2. Looking for an alternative strategy to enable the people surrounding toll-road to have business access

3. To increase the vocabularies of development theory with community-based development model

\subsection{Output}

The output of research is targeted to be published in Scopus-indexed international journal in the first year and to be made ISBN-textbook in the second year.

\subsection{Literature Review}

Spatial layout policy is government's domain, but public participation cannot be overridden. [2],[3] introduced the change of paradigm from classical administrative paradigm to new administrative one "governance". The idea of governance builds on the spirit that government no longer makes a policy dominantly, but there are two other pillars contributing to policy making, and even tend to replace the role of government, in which the role is played more dominantly by private sector, while society still keeps fighting for obtaining significant portion. For that reason, the role of state should be repositioned. At certain condition, the state should be won, as it deals with public interest. In the development of toll-road infrastructure, the prioritized one is the connection of regions including some city and regency areas, while individual cities or regencies have their own territorial planning in autonomy era. An integrated development is desirable in the development involving multi-areas [10]. Central Government's position is very strategic.

The demand for the society's control is getting stronger, when state and private's domination does not seem to be partial to public interest [7], basically the role of society in a state is determined by its contribution to policy making; therefore, the more democratic the role of people, the weaker is the role of state. The people's strong domination or otherwise is illustrated in table below. 
Table 1. Social Control of State and Society State

State

\begin{tabular}{|c|c|l|}
\hline State & \multicolumn{1}{|c|}{ Strong State } & \multicolumn{1}{|c|}{ Weak State } \\
\hline Strong Society & -- & \multicolumn{1}{c|}{ Diffused (Siera Lone) } \\
\hline Weak Society & \multirow{2}{*}{ Pyramidal (France, Israel) } & $\begin{array}{l}\text { Anarchical } \\
\text { China, } 1939-1945 \\
\text { Mexico, 1910 - 1920 }\end{array}$ \\
\hline
\end{tabular}

Source: Midgal, 1988

The stronger the role of state, the weaker will be the role of society. In the case of toll road construction, Government plays a strong role. Toll road development or construction is oriented more to the improvement of economic growth; therefore it makes the territorial condition in regency area occupying the weak bargaining position as it pays less attention to the nonmanufacture- and service-oriented local potency aspects. Biased urban development makes the public participation low and tends to weaken the economic access of people in region [10]. The social function of land use is succeeded with macro-economic interest.

Toll-road infrastructure development needs a very-wide land; the financing scheme implemented so far involves large-scale investors, without involving public participation affecting the development of toll-road. Another funding source comes from the government through basically profit-oriented State-Owned Enterprises, with limited contribution from the people and even the people are still marginalized socially and economically [1].

Table 2. Findings of Previous Studies

\begin{tabular}{|c|l|l|l|l|l|}
\hline No & \multicolumn{1}{|c|}{ Name/Year/Title } & Objective & \multicolumn{1}{c|}{ Finding } & Theory Used & Method \\
\hline 1 & $\begin{array}{l}\text { Henando de Soto (1989). } \\
\text { The Other Path Masih Ada } \\
\text { Jalan Lain: } \\
\begin{array}{l}\text { RevolusiTersembunyi di } \\
\text { Negara dunia ketiga (kasus } \\
\text { di Peru)[1] }\end{array}\end{array}$ & $\begin{array}{c}\text { To find out the } \\
\text { encouraging the } \\
\text { villages migrating }\end{array}$ & $\begin{array}{l}\text { - Identifying the 5- } \\
\text { fold increase of } \\
\text { population number } \\
\text { in the city } \\
\text { Informal sector } \\
\text { grows rapidly and } \\
\text { illegally }\end{array}$ & State Theory & Qualitative \\
\hline 2 & $\begin{array}{l}\text { Maria S.W Sumardjono } \\
\text { (2008). } \\
\text { Tanah Dalam Perspektif Hak } \\
\text { Ekonomi Sosial Budaya[9] }\end{array}$ & $\begin{array}{l}\text { Studying the } \\
\text { conversion of } \\
\text { farmland }\end{array}$ & $\begin{array}{l}\text { Law Protection for } \\
\text { productive land }\end{array}$ & $\begin{array}{l}\text { The } \\
\text { effectiveness } \\
\text { of legislation }\end{array}$ & Qualitative \\
\hline
\end{tabular}




\begin{tabular}{|c|c|c|c|c|c|}
\hline No & Name/Year/Title & Objective & Finding & Theory Used & Method \\
\hline 3 & $\begin{array}{l}\text { WINARTI (2009). } \\
\text { Negara dalam penguasaan } \\
\text { Tanah }[11]\end{array}$ & $\begin{array}{l}\text { To find out the role of } \\
\text { government, state } \\
\text { agency for land } \\
\text { affairs, court (Palace) } \\
\text { community and Local } \\
\text { Legislative Assembly } \\
\text { of Surakarta and those } \\
\text { actors' access to the } \\
\text { policy making in } \\
\text { Surakarta City }\end{array}$ & $\begin{array}{l}\text { The mastery of } \\
\text { lands in } \\
\text { autonomous area or } \\
\text { region (swapraja) } \\
\text { and badan swapraja } \\
\text { (agency for } \\
\text { autonomous area or } \\
\text { region) in Surakarta }\end{array}$ & $\begin{array}{ll}\text { - } & \text { State } \\
\text { Theory } \\
\text { Policy } \\
\text { Theory } \\
\text { - Institutional } \\
\text { Theory }\end{array}$ & Qualitative \\
\hline 4 & $\begin{array}{l}\text { Duto Sosialismanto (2015). } \\
\text { Hegemoni Negara } \\
\text { Tinjauan Ekonomi[8] }\end{array}$ & $\begin{array}{l}\text { To analyze the } \\
\text { strength of State and } \\
\text { to make it the } \\
\text { instrument for the } \\
\text { dominant class in } \\
\text { capitalist society }\end{array}$ & $\begin{array}{l}\text { Village and State in } \\
\text { economic-political } \\
\text { transformation in } \\
\text { Javanese rural areas }\end{array}$ & $\begin{array}{l}\text { State Theory in } \\
\text { the definition } \\
\text { of strong and } \\
\text { independent } \\
\text { state }\end{array}$ & Qualitative \\
\hline 5 & $\begin{array}{l}\text { Anis Basmalah and Johny } \\
\text { Yeremias (2005) Social } \\
\text { and environment } \\
\text { Reporting and auditing in } \\
\text { Indonesia, Maintaining } \\
\text { Organizational; } \\
\text { Legitimacy? }\end{array}$ & $\begin{array}{l}\text { The role and the } \\
\text { Existence of social } \\
\text { organization in } \\
\text { relation to } \\
\text { environment }\end{array}$ & $\begin{array}{l}\text { The role of social } \\
\text { organization in } \\
\text { environment }\end{array}$ & Social theory & Qualitative \\
\hline
\end{tabular}

\section{Methodology}

The study conducted was a qualitative research type. The author attempted to describe, to analyze, and to interpret what has been represented in research objective and problem statement. Through this qualitative approach is expected to represent holistically and comprehensively the phenomenon studied. A qualitative research paradigm, according to many scholars, has characteristics like interpretative, grounded research and naturalistic paradigm [5].This research described and observed a phenomenon with special character in land affairs in Solo Raya region, particularly along toll road in Boyolali Regency. [6] stated that there are some types of research that can be categorized into research with qualitative approach: ethnography, phenomenology, case study, hermeneutic, grounded theory, and action science. This study also employed grounded research with participant, observation and personal interview being method of collecting data.

\section{Finding and Discussion}

\subsection{The Welfare of Farmers Surrounding Toll Road}

Toll road in Boyolali Regency area belongs to Trans Jawa toll-road; it is a 22-km long toll road, most (80 percent) areas of which use farming land. Toll road crossing Boyolali Regency area is government's project rather than initiative project. Kris Ade Sudiyono, the Secretary General of Indonesian Toll Road Association, it uses governmental toll-road project, in which the planning by government, while the planning of initiative toll-road is conducted by 
private[12]. Initiative by enterprises contains economic motive, for example, when it is proposed by contractor they will pursue the project's contract value and when it is proposed by developer, they will improve their regional economic values.

Toll road development is intended to smooth the relationship between cities/regencies by adding the volume of road funded by BUMN (State-Owned Enterprise, Private and Central Government. Toll-road in Boyolali Regency area is funded $100 \%$ by governmental scheme. The planning stage is conducted entirely by central government and the operation stage is conducted by toll road operator (BPJT) as the paid road. It means that the toll road imposes tariff to the users as the compensation for the fund expended, of course, with the calculation of profit obtained by the company. Up to this stage, the people affected with toll road enjoy no financial benefit at all; they get only compensation for land acquisition (to those whose land is affected by toll road project. The people surrounding toll road do not get benefit at all; for that reasons, the project planning should be conducted by government comprehensively, and the people affected by toll road should be given business access and partnership capital. In long term, there will be an alternative for the people (farmers) surrounding toll road to operate business beyond farming. The result of survey and interview with populations (farmers) showed that they no longer work as farmers and try to work in other sectors, not related to the existence of toll road.

\subsection{Toll Road Development Model}

The development of toll road is in top-down nature (State's Domain) so far. It is a logical consequence of the size of project value and the national-scale development. Development planning and operation are conducted by central government (governmental project). In long term, partnership development patterns should be thought of, with an assumption about how to maintain the life sustainability of the people affected with toll-road development impact, majority of which is farmers.

The shift of livelihood of the surrounding people affected with toll road is not touched at all. Meanwhile, they are the part of toll road itself. There is no adequate compensation for them related to negative effects generated by toll road such as noise, pollution, and closed access. Neither can they enjoy the positive effect of toll road.

The result of survey and interview with people surrounding toll road showed that they expect that they can work on the land located in the edge of toll road with hard plants like mango, kelengkeng (longan), or rambutan using profit-share system. Furthermore, they expect that the toll-road construction is conducted using two entrance and exit gates in each regency/city, so that many private vehicles can transit in Regency/City crossed, thereby impacting on the growth of business in EXIT Toll.

\subsection{Business Partnership Model}

The existence of toll road should be free of society activity or sterile, in order to ensure the users' comfort and safety. The toll-road security system implemented so far uses fence located along the toll road, generating negative excess of envy among the society; thus an attempt should be taken to involve the surrounding people or to enjoy the presence of toll road through business partnership. The case of stone throwing over toll road users from the bridges on village access road is an example indicating that people surrounding the toll road is not involved. In the future, they should be involved in accessing business in the toll road existing.

The concept of Rest Area development along the existing toll-road should involve the people as maximally as possible by recruiting the people around toll road. Culinary, souvenir, and other creative businesses are expected to invite people around toll road. The result of current research showed some constraints encountered by people around toll-road: capital, people's skill 
and willingness to be entrepreneur, so that some training should be provided as the initiative of Toll Road Organizing Agency (Badan Pengatur Jalan Tol or BPJT). In addition, priority scale should be given to local people. Then, the recruitment of blue-collar workers utilizes people surrounding including gardeners, cleaning service personnel, security guard, etc.

\section{Conclusion}

1. Toll-road development policy conducted using governmental project model with contract and private initiative system with developer system (becoming state's domain) are both using paid system.

2. There is no public participation because it is top-down in nature, while the opportunity of partnership cooperation with people (community) can be found in Rest Area and Exit Toll, and limited area in the edge of Toll Road.

3. In long term, potential social conflict should be anticipated because the surrounding people affected by Toll Road have neither sense of belonging to it nor adequate access to partnership with Toll Road Organizing Agency (Badan Pengatur Jalan Tol or BPJT).

\section{Recommendation}

1. Public Participation (Bottom Up) model should be tried by giving access to the people affected with toll-road by giving the share calculated from the compensation for land imposition by means of giving compensation with proportional percentage.

2. The number of Rest Areas should be increased in each City/Regency crossed by Toll Road by prioritizing citizens or people affected by Toll Road to access business partnership.

3. To prevent the people affected by toll-road development from being deprived and to keep them existing in their residence as they can access business partnership; in addition the demand for corporate social responsibility (CSR) can be returned to the program in the region affected by toll road development.

\section{References}

[1] H. de Soto, The Other Of Parth The Invisible Revolution In The Third World. Jakarta: Yayasan Obor Indonesia, 1989.

[2] J. V. Denhard and R. D. Denhart, "The New Public Servics: Serving.” 2003.

[3] J. A. Musso and H. G. Frederickson, "Finding the individual: The spirit of public administration," Public Adm. Rev., vol. 59, no. 5, p. 448, 1999.

[4] S. Grindle Mirrele, Polotics And Apolicy Implementation On The Thurd World. New Jersey: Prince Town University Press, 1980.

[5] Yvonna S. Lincoln and Egon G. Guba, Naturalistic Inquiry. London, England: SAGE Publications, 1985. 
[6] D. E. McNabb and E. David, "Research Methods in Public Administration and Non Profit Management, Quantitative and Qualitative Approaches," ME Sharpe. Chapter, vol. 8, pp. 114-124, 2002.

[7] J. Migdal and S, Strong Society and Weak State : State - Society relations and State Capabilities in The Third World. New Yersey: Pricenton University Press, 1988.

[8] D. Sosialismanto, Hegemoni Negara : Ekonomi Politik Pedesaan Jawa. Yogyakarta: Lapera Pustaka Utama, 2001.

[9] S. S. W. Maria, "Tanah Dalam Perspektif HAK Ekonomi Sosial dan Budaya.” KOMPAS, Jakarta, 2008.

[10] B. Widodo, “Kebijakan Perkotaan dan Daerah,” Tata Guna Lahan: UNS, Press, 2013.

[11] Winarti, Kebijakan Pertanahan, Peran Kepentingan dan Akses Aletor. Surakarta: UNS, Press, 2017.

[12] Newspaper: Kompas Daily 